\title{
In This Issue: Building Blocks for Improving Practice
}

\author{
Kurt C. Stange, $M D, P b D$, Editor \\ Ann Fam Med 2014;98. doi: 10.1370/afm.1639.
}

A rticles in this issue of Annals bolster complementary pathways to improving practice.

These paths include new knowledge about what works in treatment of back ${ }^{1}$ and neck ${ }^{2}$ pain, optimizing drug treatment by knowing deadly risks, ${ }^{3}$ and factors affecting buprenorphine prescribing among trained physicians. ${ }^{4}$ Other paths include research that debunks a dietary myth, ${ }^{5}$ and identifies the highly variable course of patients after a diagnosis of mild cognitive impairment. ${ }^{6}$

In the realm of practice organization, studies show us staffing patterns in the Center for Medicare and Medicaid Services Primary Care Initiative, ${ }^{7}$ and the effects of medical assistants' career motivations and relationships with clinicians. ${ }^{8}$ Annals Journal Club features an article that synthesizes 10 building blocks of high-performing primary care. ${ }^{9,10}$ An essay on what it takes to successfully integrate behavioral health into primary care ${ }^{11}$ complements a position statement published jointly by several Annals' sponsors in the Family Medicine Updates. ${ }^{12}$

We welcome your reflections at www.AnnFamMed org.

In this issue, we wish to acknowledge two transitions, beginning with the retirement of Steve Zyzanski as Statistical Editor. Steve has been with the Annals from the outset, helping authors improve their work, helping editors make better decisions, and assuring rigorous review and clear presentation of data. He will continue as Consulting Statistical Editor.

Miguel Marino, $\mathrm{PhD}$, has joined us as Statistical Editor. Miguel is Assistant Professor of Family Medicine at the Oregon Health Sciences University. He received his $\mathrm{PhD}$ in biostatistics from Harvard University, where he completed a post-doctoral fellowship at the School of Public Health. He brings a strong interest in family medicine and primary care, and skills in statistical analysis of high dimensional correlated data, prediction, multilevel modeling, multivariate data, longitudinal analysis, and missing data methods. We are delighted to welcome Miguel to our team.

Managing Editor Claire Zimmerman has also retired. Many in family medicine know Claire. She has edited family medicine journals for three decades and has been Managing Editor of the Annals for 11 years. Claire has brought outstanding judgment, skill, patience, and good humor to her work. She will continue to work with us as a part-time manuscript editor, so we will all continue to benefit from her presence.

Our new Managing Editor is Elizabeth Anderson, MLS. Beth has served as Annals Editorial Assistant since 2003, juggling the myriad demands of publishing. She has already put her first-rate organizational and editing skills to work in this issue. We look forward to working with Beth in her new capacity.

\section{References}

1. Foster NE, Mullis R, Hill JC, et al. Effect of stratified care for low back pain in family practice (IMPaCT Back):a prospective populationbased sequential comparison. Ann Fam Med. 2014;12(2):102-111.

2. Sherman KJ, Cook A, Hawkes R, et al. Five-week outcomes from a dosing trial of therapeutic massage for chronic neck pain. Ann Fam Med. 2014;12(2):112-120.

3. Rao GA, Mann JR, Shoaibi A, et al. Azithromycin and levofloxacin use and increased risk of cardiac arrhythmia and death. Ann Fam Med. 2014;12(2):121-127.

4. Hutchinson E, Catlin M, Andrilla CA, Baldwin L, Rosenblatt RA. Barriers to primary care physicians prescribing buprenorphine. Ann Fam Med. 2014;12(2):128-133.

5. Gardner C, Oelrich B, Hope J, Vu Q, Gardner C. Effect of raw milk on lactose intolerance: a randomized, controlled, pilot study. Ann Fam Med. 2014;12(2):134-141.

6. Eisele $M$, Wiese B, Prokein J, et al. Prognosis of mild cognitive impairment in general practice: results of the German AgeCoDe study. Ann Fam Med. 2014;12(2):158-165.

7. Peikes DN, Reid RJ, Day T, et al. Staffing patterns of primary care practices in the Comprehensive Primary Care Initiative. Ann Fam Med. 2014;12(2):142-149.

8. Elder NC, Jacobson C, Fixler J, et al. Patterns of relating between physicians and medical assistants in small family medicine offices. Ann Fam Med. 2014;12(2):150-157.

9. Stange KC. Annals Journal Club. Building blocks of high-performing primary care. Ann Fam Med. 2014;12(2):iii.

10. Bodenheimer T, Willard-Grace R, Ghorob A, Grumbach K. The 10 building blocks of high-performing primary care. Ann Fam Med. 2014;12(2):166-171.

11. Kathol RG, deGruy F, Rollman BL. Value-based financially sustainable behavioral health components in patient-centered medical homes. Ann Fam Med. 2014;12(2):172-175.

12. Baird M, Blount A, Brungardt S, et al; The Working Party Group on Integrated Behavioral Healthcare. Joint principles: integrating behavioral health care into the patient-centered medical home. Ann Fam Med. 2014;12(2):183-185. 